\title{
Role of Weather Parameters on Population Build Up of Minor Insect Pests of Brinjal
}

\author{
D. K. Saikia ${ }^{1}$, R. N. Borkakati ${ }^{1 *}$, M. R. Venkatesh $^{2}$ and Sinki Barman ${ }^{3}$ \\ ${ }^{1}$ Department of Entomology, Assam Agricultural University, Jorhat-785013, India \\ ${ }^{2}$ RSK Banakal, Office of the Asst. Director of Agri, Chikmagalur, Karnataka, India \\ ${ }^{3}$ KVK, Simaluguri, Assam Agricultural University, Nagaon -782 002, India \\ *Corresponding author
}

\section{A B S T R A C T}

\section{Keywords}

Weather Parameter, Population Build Up, Minor Insect Pests of Brinjal,

Article Info

Accepted:

05 June 2020

Available Online:

10 July 2020
An experiment was carried out during rabi seasons of 2017-18 at the farmer's field, Allengmora, Jorhat to study the effect of weather parameters on population buildup of some minor insect pests of brinjal which could also play an important role for yield reduction of brinjal. Significant positive correlation of aphid, Aphis gossypii Glover $(\mathrm{r}=0.662)$ and leafhopper, Amrasca biguttula biguttul Ishida $(\mathrm{r}=0.560)$ was observed with maximum temperature. Therefore, in this context, the incidence of minor insect pests cannot be ignored for maximize the yield of brinjal crops. The different meteorological parameters, however did not show any positive significant effect against flea beetle, Monolepta signata Olivier on the population buildup of the pest during the present study.

\section{Introduction}

Brinjal (Solanum melongena L.) is a nutrient rich solanaceous vegetable cultivated throughout India. In India fromarea and production perspective, it is being cultivated approx. 7.30 lakhs hectare and produces 12.8 million metric tonnes (Anon, 2018). However, reduction on gain yield is due to the different types insect pests associated with brinjal crop (Borah et al., 2016 and Borkakati et al., 2019a) and of course conservation of natural enemies can maintain the harmful pest under economic threshold level (Borkakati et al., 2019b). Amongst insect pests though brinjal shoot and fruit borer, Leucinodes orbonalis Guenee is the major pests, but some other minor pests are also associated with brinjal crop viz., aphid, Aphis gossypii Glover; leaf hopper, Amrasca biguttula biguttul Ishida and flea beetle, Monolepta signata Olivier. (Isahaque, 1979; Dhankar, 1988; Regupathy et al., 1997 and Borkakati et $a l ., 2018)$ and these minoe insects are also 
equally important for reduction of crop yield of brinjal. However, it has been observed that a congenial atmospheric condition in any crop ecosystem always plays a dominant role in population fluctuation of insect pests irrespective of major or minor one (Begam et al., 2016; Pradhan et al., 2020).

Nevertheless, transgenic brinjal may be an alternate option for pests management similar to the future crucifers with Cry endotoxin gene (Shelton et al., 2009), but one cannot nullify the attack of other pests. In this context, due attention should be poid by the minor insect pest besides L. orbonalis in relation to meteorological parameters of the crop situation. Therefore, present study was undertaken mainly to focus on the effect of weather parameters on population buildup of minor insect pests of brinjal.

\section{Materials and Methods}

The experimental site is situated at $26^{\circ} 756^{\prime}$ latitude and $94^{\circ} 209 \mathrm{E}^{\prime}$ longitude at an altitude of $86.6 \mathrm{~m}$ above mean sea level. Field experiment was executed during rabi seasons of 2017-18 at the farmer's field, Allengmora, Jorhat under AICRP on Biological Control of Crop Pests and Weeds. For this purpose, a field with $500 \mathrm{~m}^{2}$ was cultivated by following package of practice of AAU, Jorhat except plant protection with Bio-intensive IPM module (Anonymous, 2014).

The data of insect pests were recorded from five randomly selected plants from 5 spot of $100 \mathrm{~m}^{2}$ area and observations were recorded at weekly interval based on visual count and using sweeping net. Observation on the population of sucking insect pests, aphids and leafhopper (both nymph and adult) were recorded on three leaves, one each from top, middle and bottom canopy of the five plants selected randomly in each plot (Koushik et $a l .$, 2014). Data o sucking pests were recorded as insect per leave basis, whereas the flea beetles were recorded as insect per plant basis. Meteorological data were collected from Department of Meteorology, Assam Agricultural University, Jorhat as the experimental field is situated approximately $15 \mathrm{~km}$ from AAU, Jorhat.

\section{Results and Discussion}

\section{Incidence of Aphis gossypii}

The activity (Table1 \& 2) of A. gossypii was recorded from the last week of September 2017 up to first week of January 2018 during the present investigation. The first incidence of A. gossypii was recorded on $28^{\text {th }}$ of September 2017. Afterwards, the variation in population was observed at weekly intervals during experimental study. During early stages of the crop, the activity of aphid was high and afterwards the activity of the pest was found to be declined.

However, the peak period of activity was recorded during second week of November 2017 with 4.24 aphid/leaf when the maximum and minimum temperature, average relative humidity and bright sunshine hours during the period of maximum activity of aphid were $29.3^{\circ} \mathrm{C}, 15.1^{\circ} \mathrm{C}, 79.95 \%$ and 8.6 , respectively.

The pest remained active throughout the year with a fluctuating population which was ranged from 0.41 to 4.24 aphid/leaf. The reduction of pest from second week of November might be due to variation in weather parameters and predatory action by coccinellids and spiders. From the present findings, it was clearly indicated that, the population of $A$. gossypii was increased with increasing in maximum temperature. However, the finding of present investigation was in conformity with Mall et al., (1992), according to whom the peak population of $6.86 \mathrm{aphid} / \mathrm{leaf}$ on brinjal was recorded during 
the first week of November where as Bharadiya and Patel (2005), from Gujarat also recorded peak activity of aphids during third week of November. But the present findings were not conformity with Borah and Saikia (2017) from Assam who recorded the maximum activity of aphids during February and March.

The correlation (Table3) studies of the aphid population with different meteorological parameters indicated a significant positive correlation with maximum temperature $(r=$ 0.662). Although, minimum temperature ( $\mathrm{r}=$ $0.468)$, total rainfall $(\mathrm{r}=0.180)$ and bright sunshine hours $(r=0.327)$ showed positive effect but they were not significantly associated with the population buildup of the aphid. However, average relative humidity ( $\mathrm{r}=$ -0.372) had no significant effect on the population buildup of the pest during the period of present investigation. Prasad and Logiswarans (1997) also recorded a positive association with maximum temperature and negative association with rainfall and minimum temperature. The present correlation studies of aphid population with meteorological parameters however in conformity with Borah and Saikia (2017) and according to them aphids population showed significant positive association with maximum and minimum temperature. Further, they also found that aphid showed a negative significant association with average relative humidity. But Chandrakumar et al., (2008) recorded a negative correlation with both maximum and minimum temperature, respectively.

\section{Incidence of Amrasca biguttula biguttula}

The incidence (Table1 \&2) of A. biguttula biguttula was observed on brinjal from first week of October 2017. However, the first incidence of the pest was recorded on $5^{\text {th }}$ October 2017 and remained active throughout the season with a fluctuating population of 0.49 to 3.62 adult/ leaf. Earlier workers also recorded the activity of pest throughout the cropping period (Mall et al., 1992; Chandrakumar et al., 2008 and Borah and Saikia, 2017).

During present study, the initial population of pest was 1.68 adult/leaf and it was gradually increased up to third week of October and reached its peak during second week of November 2017 with 3.62 adult/leaf. During the maximum activity period of $A$. biguttula biguttula, the maximum and minimum temperature, average relative humidity and bright sunshine hours were recorded as $29.3^{\circ} \mathrm{C}, 15.1^{\circ} \mathrm{C}, 79.95 \%$ and 8.6 , respectively with no rainfall during the peak period of activity of the pest during 2017-18.

However, the maximum activity of leafhopper was found during December as reported by Chandrakumar et al., (2008) and Indirakumar et al., (2009), respectively. From the present findings, it was found that low or no rainfall favored the population buildup of leafhopper.

When the different meteorological parameters were correlated (Table.3) with the population buildup of $A$. biguttula biguttula, it was observed that maximum temperature $(\mathrm{r}=$ 0.560) showed a significant positive correlation whereas minimum temperature $(\mathrm{r}=$ $0.414)$, total rainfall $(\mathrm{r}=0.087)$ and bright sunshine hour $(r=0.296)$ also showed a nonsignificant positive correlation with leaf hopper population whereas average relative humidity $(\mathrm{r}=-0.331)$ showed a negative association with leafhopper. It was also indicated negative correlation with maximum and minimum temperature and positive correlation with rainfall as reported by a Chandrakumar et al., (2008) and Indirakumar et al., (2016), respectively. Prasad and Logiswaram (1997) also reported significant positive association with maximum 
temperature and negative association with rainfall. However, Borah and Saikia (2017) reported that, the population of leafhopper had a positive impact with both maximum and minimum temperature while average relative humidity and total rainfall showed negative association with leafhopper.

\section{Incidence of Monolepta signata}

Trend of incidence (Table1 \&2) of $M$. signata was observed from October 2017 onward and remained active up to first week of December 2017 with a fluctuating population ranging from 0.29 to 2.71 adult/plant. Peak population of the insect was recorded on $22^{\text {nd }}$ November with 2.71 adult/plant. In the present investigation, moderately high maximum temperature had been found to be conductive for population buildup of the pest. However, Turnock et al., (1987) reported the effect of temperature on the time of emergence of adults of flea beetle which affected their ability to survive in a proper way. Correlation (Table3) of $M$. Signata population with weather parameters revealed that the parameters like maximum temperature $(\mathrm{r}=$ $0.140)$, minimum temperature $(r=0.055)$ and bright sunshine hours $(r=0.337)$ showed a non-significant positive correlation whereas average relative humidity $(r=-0.338)$ and total rainfall $(r=-0.127)$ showed a non-significant negative association with the pest. Moreover, it was observed that all the meteorological factors did not exert any positive significant effect on the population buildup of this pest during the course of investigation. However, the results of correlation coefficient (r) of present study were in agreement with the results of Chen et al., (1991) also who reported high temperature and heavy rainfall with negative correlation of $M$. signata population.

Table.1 Data of meteorological parameters during study period

\begin{tabular}{|c|c|c|c|c|c|}
\hline \multirow{2}{*}{$\begin{array}{c}\text { Period of } \\
\text { observation }\end{array}$} & \multicolumn{2}{|c|}{ Temperature $\left({ }^{\circ} \mathrm{C}\right)$} & \multirow{2}{*}{$\begin{array}{c}\text { Average } \mathbf{R H} \\
(\%)\end{array}$} & \multirow[t]{2}{*}{ Rainfall (mm) } & \multirow[t]{2}{*}{ BSSH (hr) } \\
\hline & Max & Min & & & \\
\hline 28.09.17-04.10.17 & 31.8 & 24.7 & 87.9 & 13.8 & 4.9 \\
\hline 05.10.17-11.10.17 & 34 & 24.9 & 82.8 & 0.2 & 7.5 \\
\hline 12.10.17-18.10.17 & 32.6 & 23.9 & 85.2 & 7.4 & 5 \\
\hline 19.10.17-25.10.17 & 28.5 & 22 & 90.7 & 11.4 & 2.6 \\
\hline 26.10.17-01.11.17 & 28.1 & 19.5 & 84.9 & 1 & 6.1 \\
\hline 02.10.17-08.11.17 & 29.5 & 16.6 & 79.9 & 0 & 9.2 \\
\hline 09.11.17-15.11.17 & 29.3 & 15.1 & 80 & 0 & 8.6 \\
\hline 16.11.17-22.11.17 & 28.5 & 18.7 & 82.6 & 1 & 4.9 \\
\hline 23.11.17-29.11.17 & 27 & 15.1 & 83.8 & 1.1 & 6.6 \\
\hline 30.11.17-06.12.17 & 26.1 & 11.7 & 82.7 & 0 & 7.4 \\
\hline 07.12.17-13.12.17 & 26.3 & 14.6 & 83.7 & 0 & 4 \\
\hline 14.12.17-20.12.17 & 24.7 & 13.8 & 89 & 0 & 3 \\
\hline 21.12.17-27.12.17 & 26 & 11.8 & 81.7 & 0 & 6.6 \\
\hline 28.12.17-04.01.18 & 24.9 & 11.7 & 84.6 & 0.1 & 5.8 \\
\hline
\end{tabular}


Table.2 Population buildup of insect pests of brinjal during 2017-18

\begin{tabular}{|c|c|c|c|}
\hline $\begin{array}{c}\text { Period of } \\
\text { observation }\end{array}$ & $\begin{array}{c}\text { Aphid per leaf } \\
\text { (adults/Leaf) }\end{array}$ & $\begin{array}{c}\text { Leaf hopper per leaf } \\
\text { (adults/Leaf) }\end{array}$ & $\begin{array}{c}\text { Flea beetle per plant } \\
\text { (adults/plant) }\end{array}$ \\
\hline $\mathbf{2 8 . 0 9 . 1 7 - 0 4 . 1 0 . 1 7}$ & 1.77 & 1.68 & 0 \\
\hline $\mathbf{0 5 . 1 0 . 1 7 - 1 1 . 1 0 . 1 7}$ & 3.50 & 2.37 & 0.29 \\
\hline $\mathbf{1 2 . 1 0 . 1 7 - 1 8 . 1 0 . 1 7}$ & 4.22 & 3.16 & 0.57 \\
\hline $\mathbf{1 9 . 1 0 . 1 7 - 2 5 . 1 0 . 1 7}$ & 2.16 & 2.63 & 1.29 \\
\hline $\mathbf{2 6 . 1 0 . 1 7 - 0 1 . 1 1 . 1 7}$ & 1.86 & 2.09 & 1.14 \\
\hline $\mathbf{0 2 . 1 0 . 1 7 - 0 8 . 1 1 . 1 7}$ & 3.25 & 3.28 & 1.86 \\
\hline $\mathbf{0 9 . 1 1 . 1 7 - 1 5 . 1 1 . 1 7}$ & 4.24 & 3.62 & 2.29 \\
\hline $\mathbf{1 6 . 1 1 . 1 7 - 2 2 . 1 1 . 1 7}$ & 3.74 & 3.12 & 2.71 \\
\hline $\mathbf{2 3 . 1 1 . 1 7 - 2 9 . 1 1 . 1 7}$ & 3.05 & 2.14 & 0.71 \\
\hline $\mathbf{3 0 . 1 1 . 1 7 - 0 6 . 1 2 . 1 7}$ & 1.79 & 1.90 & 0 \\
\hline $\mathbf{0 7 . 1 2 . 1 7 - 1 3 . 1 2 . 1 7}$ & 2.06 & 2.01 & 0 \\
\hline $\mathbf{1 4 . 1 2 . 1 7 - 2 0 . 1 2 . 1 7}$ & 1.45 & 1.40 & 0 \\
\hline $\mathbf{2 1 . 1 2 . 1 7 - 2 7 . 1 2 . 1 7}$ & 0.98 & 1.21 & 0 \\
\hline $\mathbf{2 8 . 1 2 . 1 7 - 0 4 . 0 1 . 1 8}$ & 0.41 & 0.49 & \\
\hline
\end{tabular}

Table.3 Correlation studies of insect pests and predators of brinjal with the weather parameters during 2017-18

\begin{tabular}{|l|c|c|c|c|c|}
\hline Insect Pests & $\begin{array}{c}\text { Maximum } \\
\text { temperature }\left({ }^{\mathbf{0}} \mathbf{C}\right)\end{array}$ & $\begin{array}{c}\text { Minimum } \\
\text { temperature } \\
\left({ }^{\circ} \mathbf{C}\right)\end{array}$ & $\begin{array}{c}\text { Average } \\
\text { Relative } \\
\text { Humidity }(\boldsymbol{\%})\end{array}$ & $\begin{array}{c}\text { Total } \\
\text { Rainfall } \\
(\mathbf{m m})\end{array}$ & $\begin{array}{c}\text { BSSH } \\
(\mathbf{h r})\end{array}$ \\
\hline Aphid per leaf & $\begin{array}{c}0.662^{* *} \\
\mathrm{y}=-5.469+0.279 \mathrm{x}\end{array}$ & 0.468 & -0.372 & 0.180 & 0.327 \\
\hline $\begin{array}{l}\text { Leafhopper per } \\
\text { leaf }\end{array}$ & $\begin{array}{c}0.560^{*} \\
\mathrm{y}=2.689+0.173 \mathrm{x}\end{array}$ & 0.414 & -0.331 & 0.087 & 0.296 \\
\hline $\begin{array}{l}\text { Flea beetle per } \\
\text { plant }\end{array}$ & 0.140 & 0.055 & -0.388 & -0.127 & 0.337 \\
\hline
\end{tabular}

** Correlation is significant at 0.01 level

* Correlation is significant at 0.05 level

Significant positive correlation of aphid and leafhopper was observed with maximum temperature. Therefore, the incidence of minor insect pests cannot be ignored for maximize the yield of brinjal crops.

\section{References}

Anonymous, 2014. Package of Practice of Horticultural Crops. Published by Department of Agriculture, Assam and Assam Agricultural University, Jorhat, pp 53-54.

Anonymous. 2018. Horticultural statistics at a glance 2018. Horticulture Statistics Division, Ministry of Agriculture and Farmers Welfare, Government of India. $10 \mathrm{pp}$.

Begam, N., Saikia, D.K., Borkakati, R. N. 2016. Seasonal incidence of major insect-pests and their natural enemies of BhutJolokia. Ann Pl ProtecSci, 24(2):259-264.

Borah, N. and D. K. Saikia (2017). Seasonal 
incidence of major insect pests of brinjal and their natural enemies. Indian J. Entomol,79(4): 449-455.

Borah, N., Saikia, D.K., Borkakati, R. N. 2016. Field efficacy of certain insecticides and biopesticides against the major pests of Brinjal and their effect on natural enemies. Pestology,XL(7):29-33.

Borkakati, R. N., Venkatesh, M.R.,Saikia, D. K. 2019a. Insect pests of Brinjal and their natural enemies. $J$ EntomolZool Stud, 7(1): 932-937.

Borkakati, R.N., Saikia, D. K., Buragohain, P.2018. Natural enemy fauna of agrihorti ecosystem of Assam. Indian J. Entomol,80(3): 658-661.

Borkakati, R.N., Saikia, D.K., Venkatesh, M.R.2019b. Habitat manipulation for managing insect pests of brinjal.Indian J. Entomol,81(4):717-720.

Chandrakumar, H. L., Chakravarthy,A. K. and PuttaRaju,T. B. 2008. Seasonal occurrence of major insect pests and their natural enemies on brinjal. Current Biotica,2(1): 66-69.

Indirakumar, K., Devi, M. and Loganthan, R. 2016. Seasonal incidence and effect of abiotic factors on population dynamics of major insect pests on brinjal crop. Int J Plant Prot,9(1): 142-145.

Isahaque, N.M.D.M. 1979. Studies on brinjal shoot and fruit borer, Leucinodes orbonalis Guen. Under Assam condition. Ph.D. Thesis, Gauhati University, Gauhati.

Koushik, N. R.,Manjunatha, M.,Shivanna, B. K. and Latha, M. 2014. Seasonal incidence of major insect pests and their natural enemies on brinjal in Shimoga, Karnataka. J. Eco-friendly Agriculture,9(1): 53-56.

Mall, N. P., Pandey, R. S., Singh, S.V. and Singh, S. K. 1992. Seasonal incidence of insect pests and estimation of the losses caused by shoot and fruit borer on brinjal. Indian J. Entomol,63(2): 137-143.

Pradhan, P. P., Borkakati, R. N., Saikia, D. K. 2020. Seasonal incidence of insect pests and natural enemies of mustard in relation to meteorological parameters. $J$ Entomol Zool Stud, 8(1): 1538-1542.

Prasad, G. S. and Logiswaran, G. 1997. Influence of weather factors on population fluctuation of insect pests on brinjal at Madurai, Tamil Nadu. Indian J. Entomol,59(4): 385-388.

Regupathy, A., Palanisamy, S., Chandramohan, N., Gunathilagaraj, K. 1997. A guide on crop pests. Sooriya Desk Top Publishers, Coimbatore, 264 pp.

Shelton, A. M., Gujar, G. T., Chen, M., Rauf, A., Srinivasan, R., Kalia, V., Mittal, A., Kumari, A., Ramesh, K., Borkakati, R., Zhao, J. Z., Endersby, N., Russell, D. A., Wu, Y.D., Uijtewaal, B.2009. Assessing the susceptibility of cruciferous Lepidoptera to Cry1Ba2 and Cry1Ca4 for future transgenic cruciferous vegetables.J EconEntomol, 102(6): 2217-2223.

Turnock, W. J., Lamb, R. J. and Bilodeau, R. J. 1987. Abundance, winter survival and spring emergence of flea beetle in a Manitoba grove. Can Ent,119(5): 419426.

\section{How to cite this article:}

Saikia. D. K., R. N. Borkakati, M. R. Venkatesh and Sinki Barman. 2020. Role of Weather Parameters on Population Build Up of Minor Insect Pests of Brinjal. Int.J.Curr.Microbiol.App.Sci. 9(07): 397-402. doi: https://doi.org/10.20546/ijcmas.2020.907.044 